\title{
FORUM
}

Submitted 09.08.2015. Approved 06.13.2016

Evaluated by double blind review process. Scientific Editors: Glenn Morgan, Marcus Vinícius Peinado Gomes and Paola Perez-Aleman DOI: http://dx.doi.org/10.1590/So034-759020160407

\section{TRANSNATIONAL GOVERNANCE AND THE TRILHOS URBANOS: CIVIL SOCIETY'S RESISTANCE TO MEGA- EVENTS IN RIO DE JANEIRO}

\author{
Governança transnacional e os Trilhos Urbanos: Resistência da sociedade civil a \\ megaeventos no Rio de Janeiro \\ Gobernanza transnacional y los Trilhos Urbanos: Resistencia de la sociedad \\ civil a los megaeventos en Rio de Janeiro
}

\begin{abstract}
Mega-events are urban spectacles that bring together capital, physical materials, symbols, people and organizations, to produce sports and cultural events. Rio de Janeiro hosted the soccer World Cup in 2014 and will shortly host the 2016 Olympics, two such Mega-events. This paper discusses these Mega-events in terms of a new and influential model of transnational governance that involves market-based alliances between urban leaders, real-estate developers, global corporations and sports-related civil society groups. It begins by defining mega-events and their significance to transnational governance, and then describes the mega-events being held in Rio de Janeiro. In the final section, the implications of these mega-events are reviewed, highlighting the on-going period of contestation within urban visions of transnational governance.
\end{abstract}

KEYWORDS | Social management, environmental management, critical theory, urban management, Brazilian politics.

\section{RESUMO}

Os megaeventos são espetáculos urbanos que reúnem capital, materiais físicos, símbolos, pessoas e organizações, para produzir eventos culturais e esportivos. O Rio de Janeiro sediou a Copa do Mundo de 2014, e, em breve, sediará os Jogos Olímpicos de 2016, dois desses megaeventos. Este artigo discute tais megaeventos em termos de um novo e influente modelo de governança transnacional envolvendo alianças baseadas em mercado entre líderes urbanos, incorporadoras, corporações globais e grupos da sociedade civil relacionados aos esportes. O artigo começa definindo os megaeventos e seu significado para a governança transnacional, e, em seguida, descreve os megaeventos que estão sendo sediados no Rio de Janeiro. Na seção final, as implicações destes megaeventos são revistas, ressaltando o período atual de contestação no âmbito das visões urbanas de governança transnacional.

PALAVRAS-CHAVE / Gestão social, gestão ambiental, teoria crítica, gestão urbana, política brasileira.

\section{RESUMEN}

Los megaeventos son espectáculos urbanos que unen capital, materiales físicos, símbolos, personas y organizaciones, para producir eventos deportivos y culturales. Rio de Janeiro fue sede de la Copa Mundial de Fútbol en 2014 y en breve lo será de las Olimpíadas 2016, ambos megaeventos. El presente artículo trata los megaeventos en términos de un modelo nuevo e influyente de gobernanza transnacional que involucra alianzas de mercado entre líderes urbanos, constructoras inmobiliarias, corporaciones globales y grupos de la sociedad civil relacionados con los deportes. Comienza definiendo los megaeventos y su significado para la gobernanza transnacional y entonces describe los megaeventos realizados en Rio de Janeiro. En la parte final, se revén las implicaciones de dichos megaeventos, destacando el período actual de oposición dentro de los puntos de vista urbanos de la gobernanza transnacional.

PALABRAS CLAVE / Gestión social, gestión ambiental, teoría crítica, gestión urbana, política brasileña.

srinivan@newschool.edu

Professor at The New School - New York - NY, United States of America 
“...O melhor o tempo esconde,

longe, muito longe

mas bem dentro aqui

quando o bonde dava volta ali...

bonde da Trilhos Urbanos

vão passando os anos

e eu nã te perdi,

meu trabalho é te traduzir..."

“...The best time hides

Far, far away

but here right inside

when the tram turns around over there...

the tram of the Trilhos Urbanos

the years go by

and I haven't lost you,

my work is to translate you.."

(Caetano Veloso, Trilhos urbanos, 1979)

\section{INTRODUCTION}

Rio de Janeiro is globally renowned for its stunning landscapes and its major spectacles. What is less well known, however is the fact that the city is currently at a landmark moment in its history, with the implementation of a particular model of urban management that is closely linked to changing ideas in governance, especially in terms of the role of markets and states in serving and responding to the needs of citizens. This paper describes this specific new model of urban governance, that of the mega event, which involves a market-based alliance to promote highly visible sporting events, and begins by defining mega-events and their significance to transnational governance. A description then follows of the mega-events occurring in Rio de Janeiro, and civil society's response to them. The final section discusses the implications of these urban visions to transnational governance.

This paper is based on the perceptions and arguments of a variety of people who were interviewed over a month-long period in July 2013, when the author received funding from the BRICS Policy Center in Rio de Janeiro to carry out a research visit. In order to study civil society's response to mega-events, twenty interviews with activists, academics, urban planners and civil society leaders were conducted. The goal of these interviews was to register the perceptions of people at the time in relation to the impending World Cup and Olympics, as well as to register their views in relation to certain more pressing urban issues facing the city. An initial report of the findings was presented at the BRICS Policy Center, Rio de Janeiro, in August of 2013.
It is generally understood that governments control nationstates, protect their territorial assertions, serve citizens, and respond to unexpected contingencies such as emergencies and disasters. Governance is a common term for such an understanding, recognizing that such tasks also require that rules of law be established and implemented, ensuring robust institutions of governance, as well as modes of regulation and surveillance of citizens and territorial populations (Rose, 1996). Increasingly, however, this understanding is moving away from its exclusive focus on the domestic context. Investment flows in the form of multinational capital, ideas and information that use social media, internet and satellite television, theories and policy models that use interlinked academic networks and universities, are just some examples of how governance is no longer solely a domestic issue but also a transnational one.

It is tempting to laud the idea of transnational governance; it points to the limits of nation-state sovereignty and in that sense towards the possibility of global citizens holding a variety of nation-states genuinely accountable to citizens and constitutions. It also points towards ideals of cosmopolitanism and a global civil society. But rather than presume normative content, it is perhaps more appropriate to assess the actors and goals of transnational governance. These actors can have very different views on their roles and responsibilities, particularly in terms of the boundaries between market competition and state welfare (Hickey, 2012; Liow, 2012). This paper presents a case of transnational governance that deals with the context of urban leaders trying to regenerate decaying infrastructure, rejuvenate abandoned industrial sites, and attract skilled labor and capital to their city. It argues that an influential model of contemporary transnational governance makes use of major urban spectacles as a medium for urban redevelopment. While the mega event undoubtedly provides a necessary reconfiguration of stagnant urban landscapes, it also serves as a neoliberal intervention that weakens the historical rights of urban residents. The model is generated through transnational flows of ideas and capital, and can be seen, in that sense, as a form of transnational governance. However, civil society's response also has a transnational dimension, especially as urban activists in one location are often inspired by struggles that are taking place elsewhere.

\section{MEGA-EVENTS}

Mega-events are major urban spectacles that mobilize a city by acting as vectors for significant capital investment, in the hope of accelerating consumption. There are examples of the mega event model in history, such as the Great Exhibitions of London 
and Chicago (in the mid-19 ${ }^{\text {th }}$ Century) (Hall, 2006). Through these, urban leaders sought to present their cities in a favorable and highly visible light, turning their cities into veritable spectacles, largely based on alliances between prominent industrialists and the state (Black, 2007; Roche, 2006). Contemporary megaevents are especially associated with efforts to brand cities, where urban landscapes become associated with standardized images and related associations (Hannigan, 1998; Kellner, 2003). An early example of this kind of branding can be seen in the "I New York" logo. David Harvey (2005, p. 47) has argued that this logo's prominence came on the back of major cut-backs in state spending in New York City during the 1970s, when it suffered a severe fiscal crisis, and an associated determination to turn the city into a hub of tourism. Branding a city is necessary if one wants to generate an urban image that is conducive to mass tourism. Mega-events, due to the high levels of investment required, and the necessary alliances that have to be made between realestate developers, city government officials, and urban managers, help reconfigure the way in which urban markets function. They offer new ways of generating revenue and profits by freeing up existing land for new uses (Weber, 2002). Abandoned warehouses, decaying dock yards, rusting railway lines, fallow estates, can all now become stadiums, transport hubs, athlete's housing and renewed infrastructure for urban use.

Mega-events as a means of improving existing urban infrastructure offer obvious benefits. They encourage privatepublic partnerships at a time of state funding cutbacks and alarming levels of global inequality. They offer a means to rediscover cities and renew their residents' pride in them. It could then be argued that they help rejuvenate cities in as practical a way as is possible in our current climate.

On the other hand, critics note the violence and disruption that invariably come with such urban investment. Abandoned land and decaying infrastructure are not necessarily empty spaces. They can be claimed by the poor and have shantytowns built on them. In a sense these are plots of land that are already settled and used. Mega-events often lead to violent efforts to remove people from the land, resettle them, with or without compensation and in situations where there may or may not be legal claim to the land. To middle-class residents, such urban investment also represents a private cost, with rents and home-buying costs invariably rising dramatically. Private-public partnerships translate into subsidies offered to private developers by city governments. There is also therefore a tremendous public cost involved in the paradoxical effort to enhance private ownership of the city. Overall, critics of mega-events note a pattern of hasty, authoritarian urban decision-making that is usually backed by repressive enforcement mechanisms, which represent an ominous pattern of city governance (Gaffney, 2010, 2012; Menon-Sen, 2010).

Whether we agree with the critics or focus instead on the practical or more optimistic benefits of mega-events, they undeniably represent a distinctive and novel form of urban management and governance. Well known models of urban management, such as Baron Haussmann's Paris required the raising of private capital and the commitment of state funds. However, they also helped delay the advent of capitalist crises of accumulation, enabling state governments to commit much needed capital to enable further investment, consumption, production and employment (Harvey, 2012). In contrast, what is unique to the contemporary model of the mega event is that it escalates the process of gentrification, while at the same time making very little effort to address questions of urban access and equality. This escalation is marked by intensified "partnerships between private capital and the local state, resulting in larger, more expensive, and more symbolic developments, from Barcelona's waterfront to Berlin's Potsdamer Platz" (Smith, 2002, p. 441). It is also marked by the intensified targeting of global capital, for instance, in terms of financing, choice of developers, and the customers sought. Heightened security and a strong police presence effectively help quash any resident opposition to such efforts at gentrification. While the process of gentrification tends to move outwards from historical city centers to newer areas of settlement, it also has a dramatic effect on the urban landscape. Unlike prior waves, which were dependent on public financing and some attention to social goals, such "third-wave gentrification has evolved into a vehicle for transforming whole areas into new landscape complexes that pioneer a comprehensive classinflected urban remake" (Smith, 2002, p. 443). Residential use is now combined with explicit opportunities for shopping, gastronomy and culture as well as related employment, producing "whole new complexes of recreation, consumption, production, and pleasure, as well as residence" (Smith, 2002, p. 443).

\section{The mega-events in Rio}

The city of Rio de Janeiro's investment in the World Cup and the Olympics has been concentrated on three significant urban developments over the past decade. Each of these developments has represented an effort by the city's managers to redesign the urban landscape for investment and profit purposes. Furthermore, each one of these developments has a class dimension to it, with the upper and middle classes seeking very different interests to those of the poor and disadvantaged classes.

The first of these developments has involved a shift in real estate investment away from the historic city center, the Centro 
and further westward. The early heart of the city was located in and around Rio Branco Avenue, with the neighborhoods of Flamengo and Botafogo representing the westward borders. In the late 1940s, the area known today as Copacabana was opened up to settlement. The city's gradual expansion, from Copacabana through Ipanema, the Lagoa and Leblon, eventually reached its limits in Barra de Tijuca. Rio's current expansion is in this same direction, past Barra de Tijuca and further westward. Accompanying this expansion has been an effort to reclaim derelict and abandoned areas in the city, notably the docklands region of Gambõa, and the area from where the Niteroi ferries run. It is this push in urban investment that explains part of the logic of the mega event venues chosen. The new venues under construction are all on a trajectory that pushes the Zona Sul further outward, moving the locus of Rio de Janeiro away from its historical center and towards more recent conurbations.

The second of these developments involves the much publicized favela or slum district pacification campaigns. City planners have coordinated with law enforcement and social welfare agencies, and NGOs, to first invade existing favelas, battle the criminal gangs in charge, expel them, and then leave a permanent police presence to offer residents protection and security. In the process, these non-legal residents become quasi-legalized, eligible to receive certain utilities through the state, whereas earlier such access was only available through the criminal gangs that controlled the locality. However, this pacification of the favelas has not been undertaken solely for the benefit of those living in them. Crime-ridden violent favelas are a common theme in narratives about Rio de Janeiro and other large Brazilian cities. They are a feature of fiction, movies and even telenovelas, and certainly a fixture in media reporting (see Lacerda, 2015, 2016). They therefore constitute an embarrassment and a threat to city planners seeking mass tourism for their megaevents. At the same time, pacification opens up new spaces for consumption and investment that were hitherto closed due to the non-legal and hazardous nature of these settlements. Residents can now become customers of cable TV companies, apply for credit cards and for cell phones and, in short, become legitimate consumers. Some of the favelas are also quite close to prestigious locations, such as Ipanema (Cantagalo) and São Conrado (Rocinha), and constitute significant real estate in their own right, even featuring on Airbnb. This pacification can be interpreted then as part of an ongoing, albeit relatively benign effort, to contain the poor and rehabilitate them into urban society.

The third development of note involves a dual shift in Brazilian urban politics, in which urban planners seek out global alliances while prior local coalitions are re-aligning. Urban managers in places like Rio de Janeiro are aware, more than ever before of the existence of global interconnections. Ideas on urban management spread from one location to another through networks of not only capital and real-estate developers, but also media, NGO conclaves and international conferences. Rio is, in this sense and as these managers see it, claiming its space in the global imagination. Whereas in the past Rio de Janeiro, an early and prominent settlement which was the residence in exile of the King of Portugal, the national capital until 1960 and a city vital to the culture and politics of Brazil, could claim its prominence in terms of national identity, today, like other major cities, it must claim its prominence in terms of its global links and connections. One of these links of great importance is that with the so-called BRICS group. The BRICS nations include Brazil, Russia, India, China and South Africa and this group of major developing economies claims an affinity between its members that is distinct from traditional colonial and geopolitical links (Black, 2007). Urban managers in Rio are, therefore well aware that they are following in the footsteps of mega-events previously held in Beijing, Shanghai, New Delhi, Johannesburg, Cape Town, Sochi, and Shanghai. Rio as a global city needs to be attractive to global investors, and especially the oligarchs of these countries (Vainer, 2013). Indeed, the municipal government of Rio partly funds the BRICS Policy Center, largely because it has already perceived the importance of the BRICS group as a prestigious global marker.

At the same time, the contemporary urban moment in Rio de Janeiro goes against the political will that has marked Brazilian politics since the return of democratic rule in 1985 . Successive governments, notably those of Fernando Henrique de Cardozo and Luiz Inácio Lula de Silva have sought to steer the nation-state's policies along a fine line between its social divides, seeking to increase foreign direct investment and exports, while at the same time committing to social spending through innovative measures such as the Bolsa Familia program. While singularly successful in steering between these sources of pressure during Lula's reign, the ruling Partido dos Trabalhadores (PT) has come under fierce criticism during the administration of Lula's successor, Dilma Roussef. A major catalyst for this has been the extraordinary level of federal and state government spending on the World Cup and the Olympics. A variety of political groups have argued that this spending has been poorly conceived and widely misused, causing a serious shortfall in much-needed government spending. Massive protests erupted when subway fares were raised in Rio de Janeiro and São Paulo in 2013. Since then, protests of different kinds have evolved significantly into an uncontrollable third force, one that is not quite part of existing political alliances, and not quite apart from them either, a robust coalition of unions, students, workers, activists, intellectuals, all seeking a different political agenda for their country. 
This third force has played a significant role in the manner in which urban planners have prepared for these mega-events. The successful Olympic bid, as well as the media attention it has attracted have focused on claims that Rio de Janeiro is now a global city, and that such mega-events offer an excellent opportunity for it to extend Brazil's global footprint as a counterweight to the hegemony of the United States and Europe. Similarly, the protests that have taken place against these megaevents and the practices and policies of Rio's mayor Eduardo Paes, have also been focused on global influences and impacts. Protesters have taken inspiration from anti-austerity protests in Greece and Spain and protests in favor of democratic reform in Tunisia, Egypt, and Turkey. This inspiration has at times had ironic resonances. For instance, during the author's research visit to Rio, one interviewee remembered a demonstration he attended where the protesters began to chant 'Brazil is not Turkey', to indicate that the human rights abuses being committed by the Brazilian police were becoming comparable to those committed in Istanbul during the Gezi Park demonstrations. These protests in Brazil have been successful and highly visible, thanks to the alliances that have been established between groups unhappy with the policy choices of the current PT leadership.

\section{Civil society's response to these mega-events}

Despite the impressive and well-coordinated efforts to mount the Olympics in Rio de Janeiro, there have been equally impressive and coordinated efforts to challenge these mega-events. Civil society groups have sought to delegitimize the afore-mentioned policies. They have also sought to open up urban spaces for collaboration and inclusion, and called for a debate over cities and social justice. Initiatives offered by the authorities, such as the building of the teleféricos, cable cars that make it easier to travel up the steep terrain of the Rocinha favela, have been heavily criticized as being totally inadequate when compared to the urgent need for sewage facilities and crèches, for example. In addition, cable cars require towers to be constructed, which means demolishing existing squatter homes. Activists interviewed by this author questioned whether these measures were actually desired by residents or whether they were aimed at beautifying these areas for the upcoming Olympics.

Such mega-events have become flashpoints in the construction of alternative urban policies, and the aim of these activists is to ensure that citizens are more involved in the decisions taken on their behalf by the city's government. For instance, the decision to demolish the unpopular elevado, an important elevated highway leading out of the city center towards the airport, Niteroi and São Paulo, ignored any debate over possible alternatives, including new uses for the viaduct. Instead, the city's government decided to demolish the highway and construct a series of tunnels, at a very high cost. The issue here was not necessarily whether the decision was the correct one but rather the manner in which the decision was taken, without an effort made to discuss the issue with Rio's citizens. Urban intellectuals and professionals interviewed by this author also raised questions about the city's urban planning process and the decisions taken. The city's much-vaunted new transport hubs include bus stations, subway stations, and stations for the teléferico cable-cars in the historic docklands and abandoned warehouse regions. However, these hubs are not interconnected and seem to be intended solely for specific populations, such as the favela residents, in the case of the teléfericos for instance. Better urban planning is essential to avoid transport gridlock, such as, in the case of the narrow roads that now stretch out further from the Zona Sul. These roads could not, however be sufficiently widened because of the steep cliff faces that border the Atlantic Ocean. Finally, a variety of non-profit groups have worked with the city authorities, some closely, some with a more detached and critical attitude, to better prepare the city's residents for the impending Olympics. All these responses have been largely non-violent and used the social media to challenge and push back the neoliberal mega event.

This section outlines three organizational types of civil society that have marked their presence in Rio de Janeiro during this period. Each has been significant in challenging the policy assumptions underlying these mega-events, as well as in terms of directly confronting and undermining the efforts to hold the events. The first of these organizational forms involves informal grassroots clusters of activists, coordinating their activities through the social media. This structure has been a dominant force behind the confrontations, which have included both spontaneous and coordinated demonstrations protesting against the mega-events. Organizationally, their activities have been characterized by a high degree of informality in terms of recruiting participants, as well as flexibility in terms of response. This has allowed for a good level of adaptability. However, it has not provided sufficient stability or resources to be able to challenge the significant urban infrastructure decisions being taken. Activists tell the author that their emphasis is on local involvement, especially in the favelas. Informal meetings and scheduled forums have been used to inform residents of the city's decisions as well as to coordinate a response to these. On occasion, these activists also work with formal coalitions, such as unions representing teachers and workers, in coordinating their protests.

A second organizational type involves formal organizations whose mission has indirectly had an impact on 
the urban policies in the city. A host of NGOs and established social movements have been passively and actively confronting the city's urban policies. A good example of this is the non-profit organization, Galpão Aplauso, which works with the inner-city youth, helping them acquire useful productive skills that can ensure their future employment. The Galpão also encourages its students to consider starting social enterprises, with some support from sympathetic employers and financiers. In its work, two aspects stand out. The organization is founder-driven, led by a charismatic leader who through her vision and dedication ensures support and funding. Her personal intercession ensures credibility and legitimacy. At the same time, the staff emphasizes a sensitive, inclusive and non-threatening approach to teaching. Students are encouraged to embrace their own cultural upbringing rather than repress it. Teaching examples are based on their common experiences. Classes alternate between useful and employment-oriented topics and a variety of performance related training, creating an unusual and varied teaching environment (Faria, Wanderley, Reis, \& Celano, 2013).

The organization's offices and training facilities are located in Gambõa, the historic docklands and warehouse district of Rio de Janeiro, and the region that is undergoing the most radical transformation as a result of the mega-events. However, non-profit organizations such as the Galpão do not directly engage in the debate over the city's policies as such. They do not share their views on mega-events and the city's policies towards them in either their classes or in their declared mission. It is only in informal conversations that their views on these mega-events actually emerge, as they comment on the difficulties and changes being imposed on the lives of those living in the area.

A third organizational type is explicitly opposed to the city's policies and assumes a confrontational stance. This involves non-profit organizations with formal structures that emphasize three sets of activities. Firstly, they gather information from local residents in order to document their lives; secondly, they assemble this information in a highly visible way so that residents also feel a great need to participate and become inspired by the struggle taking place in their backyard: and, thirdly, they share the information they have gathered through media channels, and in a manner that mimics and implicitly challenges the efforts of the city authorities. One such organization has put forward the Popular Plan for the Vila Autódromo (Associação de Moradores e Pescadores da Vila Autódromo, 2013). The Vila Autódromo is a community inhabited by people who have already been resettled from previous squatter settlements. The infrastructure expansion needed for the Olympics has required that these residents be reallocated once again and their squatter homes be demolished. They have of course resisted these plans. This has been a deliberate effort at urban planning, but one with a difference. Rather than relying on the city and its available data, the group representing the residents has assembled its own information in a systematic manner. In the process, this initiative has served to legitimize the lives of those being documented as well as to challenge the narratives of those representing the city. This popular plan offers alternatives to the stated aims of the urban authorities and presents a pointed challenge to the official city narrative regarding these mega-events and their expected benefits.

\section{DISCUSSION}

What do mega-events in general and the developments in Rio de Janeiro specifically signify in terms of transnational governance and civil society?

The urban vision underlying Rio's mega-events can be characterized as neoliberal. Turner (2008, pp. 4-5) identifies four features of contemporary neoliberalism: The emphasis on the market as "an indispensable mechanism for efficiently allocating resources and safeguarding individual freedoms"; "advocacy of minimal state intervention", including state welfare as "a residual system of provision" only; emphasis on private property and its protection at all costs; and an expectation that individual freedoms will be strengthened through such policies. All these features are present in the manner in which such mega-events are being promoted in Rio as vehicles of urban regeneration. The City's mega-events have required significant state subsidies, subsidies that have led to outrage and protests from a variety of social movements and political observers across Brazil. These subsidies have been made possible thanks to the close working relationship between urban developers, such as Carlos Carvalho, and the Mayor of Rio, Eduardo Paes, and come with explicit provisions for the non-implementation of existing urban regulations. Carvalho's investment is especially prominent in the areas around Barra de Tijuca, where Rio de Janeiro has room to expand away from the existing and prominent settlements of the Zona Sul, offering new avenues for future real-estate investment. Carvalho has been quite explicit in declaring the intention behind his investments, which is to create an urban community of the wealthy, insulated from the poor, self-sufficient and an autonomous bubble of affluence, protected from the realities of Rio. Carvalho insists that the quality of the accommodation must match the tone of an exclusive privileged area. "We think that if the standards were lowered, we would be taking away from what the city - the new city - could represent on the global stage as a city of the elite, of good taste" (quoted in Watts, 2015). 
As a model of transnational governance, mega-events also represent a close interplay between neoliberal thinking and managerial ideas and experience. The urban partnerships required to mount undertakings as expensive as the Olympics, involve exclusive profit-making agreements with corporations, negotiated by sports-related civil society groups (Dolles \& Söderman, 2008). Priced seating at venues, exclusive franchises and separate VIP access on public roads are all common aspects of the agreements negotiated by the Fédération Internationale de Football Association (FIFA) for the World Cup, and by the International Olympic Committee (IOC) for the Olympics. Both FIFA and the IOC are registered non-profit organizations. These agreements offer corporate sponsors attractive opportunities to profit from the events. In order to do so, however, they require city governments to explicitly cede governance and control to private powers (Vainer, 2011). Thus, the Olympics in Rio de Janeiro will have extensive private security personnel able to act autonomously from the city's police forces, while at the same time being funded by public money (Gaffney, 2011). State control of the city will suddenly be transformed into corporate control of the city. Such agreements are logical extensions of existing corporate marketing practices where consumer demand is tightly segmented in order to create more distinctive branding opportunities. However, it is now the urban landscape that is branded as a distinct product of consumption, and governance of the city is transferred away from the public authorities to a shifting alliance with multinational and local capital. In this way, mega-events help to innovate new forms of urban management, promising private actors state subsidies in order to free up real estate for a quick profit. At the same time, these events demonstrate an affinity between models of urban development and corporate practices. Neoliberal urban development uses corporate methods to generate declared public goals. The consequence of this is that the participative and communitarian aspects of such sports events become less important as they are increasingly geared towards promoting spectacles of consumption, underwritten by advertising campaigns for profit. Sport becomes an opportunity to commodify the city further, to leverage urban spaces as a branded product that serves the needs of affluent global consumers. These are the same people who seek the best Malbec in Buenos Aires, Ceviche in Lima, a perfect houseboat for the inland lagoons of Allepey, and the ideal Ragù in Emilia Romagna. It is for this sort of image that Rio is competing through its mega-events, to grab the attention of demanding global pleasure seekers.

There is little doubt that the present moment can then be seen in this light, as an accommodation of the state in favor of global capitalist forces. But it would be misleading to see such an accommodation as consensual, as complete and as concluded. Historically, the dominant form of governance in Latin American societies has incorporated a form of 'passive revolution' in Gramscian terms, that is to say "a revolution from above" where elite groups have sought to use the state to incorporate (at times forcibly) non-state actors into global trade flows and expanding markets. This history of development has involved "elite-engineered social and political reform" that has drawn "on foreign capital and associated ideas while lacking a national popular base" (Morton, 2010, p. 317). Those not benefiting from such reforms have always challenged them, requiring state and capital to find ways to accommodate or eliminate their resistance. For these reasons, such mega-events in Brazil will always be contentious. Indeed, "we have to think about the collision between three different social projects marketization, social protection and emancipation - and look at how these projects collide and become ambivalent as they interact" (Nancy Fraser, quoted in Chhachhi, 2011, p. 312). These mega-events are in this sense an unfinished experiment, a vehicle for shifting away from past models of urban management to new innovative alliances between market and state actors that has stalled. In response, alternative possibilities of transnational governance are being raised, notably through the protests of urban residents of the South, who have linked their demands to broader questions of equality and justice, democratic rights and urban access, and to competing visions of Latin American identity and development policies.

\section{IMPLICATIONS}

It is, as yet, unclear whether the market-based alliances promoting these mega-events can respond nimbly to the dismay, demands, and dissent of Brazil's citizens. Just as leaders look towards neoliberal governance methods in other countries, in order to rejuvenate their cities, civil society actors in Rio have taken inspiration from the urban struggles taking place in Istanbul, Barcelona and Athens, among others, in their response to these governance methods. The transnational dimensions of civil society's actions in Rio means that its citizens can amplify their claims in other cities and in other countries, which will, in turn be taken up elsewhere, in a continuing struggle for influence. This kind of urban governance, and the resistance to it by citizens are still on-going processes. As urban residents increasingly mobilize through protests and demonstrations, it is quite possible that this emerging form of transnational urban governance will be modified, or even rejected, in favor of some alternative. It is on this terrain of civil society, both 
among formal registered organizations as well as ongoing and shifting social alliances, that the future trajectory of this form of urban governance will be determined. These shifting coalitions "can be understood, in Gramscian terms, as part of a 'war of position' - a prolonged struggle within political and civil society to contest and reconstruct the common sense understandings of the world" (Chodor, 2015, p. 11). Further organizational research is needed into such informal and formal groupings of civil society organizations and their struggles in contemporary Brazil, and into the ways that contestation and collaboration occur between such actors as they lay out their distinct claims for transnational governance.

In his song, Trilhos Urbanos, Caetano Veloso, the wellknown Brazilian musician nostalgically describes the city of his childhood, Santo Amaro da Purificação, in Bahia. The song lovingly marks out the routes and memories of a city, from the street where you could watch an open-air movie for the very first time, to a spot where the Emperor was said to have urinated. In a sense, Caetano is memorializing the city, claiming his own particular right of interpretation, and reminding us that these urban spaces and trails are pregnant with memories and possibilities. It is not yet clear how one will be able to memorialize the trilhos urbanos of Rio de Janeiro, as the city awaits the Olympics and their aftermath, as parts of the city are destroyed, residents uprooted and resettled, and new localities created. Instead, the urban trails, and the memories they evoke, remain an invitation for radical response and further struggle, for re-imagining the possibility of social inclusion and equality in Rio de Janeiro, Brazil and elsewhere.

\section{AUTHOR'S NOTES}

My sincere thanks to Mariana Prandini Assis, for her assistance with translating the epigraph. Alexandre Faria, Carlos Vainer, Christopher Gaffney and Daniel Lacerda all helped me better understand their city and I am very grateful to them.

I would like to stress that the then-Director of the BRICS Policy Center strongly suggested, using false claims, that my presentation was on an entirely different research topic. Confidential conversations with staff later confirmed that the then-Director was seeking to downplay the attention being paid to the protests, nervous about reactions from the city's government that partly funded the center.

\section{REFERENCES}

Associação de Moradores e Pescadores da Vila Autódromo. (2013). Plano Popular da Vila Autódromo. Retrieved from https://comitepopulario. files.wordpress.com/2012/08/planopopularvilaautodromo.pdf

Black, D. (2007). The symbolic politics of sport mega-events: 2010 in comparative perspective. Politikon: South African Journal of Political Studies, 34(3), 261-276. doi:10.1080/02589340801962536

Chodor, T. (2015). Neoliberal hegemony and the Pink Tide: Breaking up with TINA? New York, USA: Palgrave.

Dolles, H., \& Söderman, S. (2008). Mega-sporting events in Asia Impacts on society, business and management: An introduction. Asian Business \& Management, 7(2), 147-162. doi:10.1057/ abm.2008.7

Faria, A., Wanderley, S., Reis, Y., \& Celano, A. (2013). Can the subaltern teach? Performativity otherwise through anthropophagy. In V. Malin, J. Murphy, \& M. Siltaoja (Eds.), Getting things done: Dialogues in critical management studies (vol. 2, pp. 205-224). Bingley, USA: Emerald Group Publishing Limited

Chhachhi, A. (2011). Nancy Fraser: Interviewed by Amrita Chhachhi. Development and Change, 42(1), 297-314. doi:10.1111/j.14677660.2011.01691.x

Gaffney, C. (2010). Mega-events and socio-spatial dynamics in Rio de Janeiro, 1919-2016. Journal of Latin American Geography, 9(1), 7-29.

Gaffney, C. (2011, November). The mega-event city as neo-liberal laboratory: The case of Rio de Janeiro. Paper presented at the Second Mega-event Think Tank, University of British Columbia, Canada.

Gaffney, C. (2012). Securing the Olympic city. Georgetown Journal of International Affairs, 13(2), 75-82.

Hall, C. M. (2006). Urban entrepreneurship, corporate interests and sports mega-events: The thin policies of competitiveness within the hard outcomes of neoliberalism. The Sociological Review, 54(Suppl.), 59-70. doi:10.1111/j.1467-954x.2006.00653.x

Hannigan, J. (1998). Fantasy city: Pleasure and profit in the postmodern metropolis. London, UK: Routledge.

Harvey, D. (2005). A brief history of neoliberalism. Oxford, UK: Oxford University.

Harvey, D. (2012). Rebel cities: From the to the right to the city to the urban revolution. New York, USA: Verso.

Hickey, S. (2012). Turning governance thinking upside-down? Insights from 'the politics of what works'. Third World Quarterly, 33(7), 1231 1247. doi:10.1080/01436597.2012.695516

Kellner, D. (2003). Media spectacle. London, UK: Routledge.

Lacerda, D. S. (2015). Rio de Janeiro and the divided state: Analysing the political discourse on favelas. Discourse \& Society, 26(1), 74-94. doi:10.1177/0957926514541346

Lacerda, D. S. (2016). The production of spatial hegemony as statecraft: An attempted passive revolution in the favelas of Rio. Third World Quarterly, 37(6), 1083-1101. doi:10.1080/01436597.2015.1109437

Liow, E. D. (2012). The neoliberal-developmental state: Singapore as case study.Critical Sociology,38(2), 241-264. doi:10.1177/0896920511419900

Menon-Sen, K. (2010). Delhi and CWG2010: The games behind the games. The Journal of Asian Studies, 69(3), 677-681. doi:10.1017/ so021911810002056

Morton, A. D. (2010). The continuum of passive revolution. Capital \& Class, 34(3), 315-342. doi:10.1177/0309816810378266 
Roche, M. (2006). Sports Mega-Events, Modernity and Capitalist Economies: Mega-events and modernity revisited: Globalization and the case of the Olympics. Sociological Review, 54(Suppl. 2), 25-40. doi:10.1111/j.1467-954x.2006.00651.x

Rose, N. (1996). Governing "advanced" liberal democracies. In A Barry, T. Osborne, \& N. Rose (Eds.), Foucault and political reason: Liberalism, neo-liberalism and rationalities of government. Chicago, USA: The University of Chicago Press.

Smith, N. (2002). New globalism, new urbanism: Gentrification as global urban strategy. Antipode, 34(3), 427-450. doi:10.1111/14678330.00249

Turner, R. S. (2008). Neo-liberal ideology: History, concepts and policies. Edinburgh, Scotland: Edinburgh University.
Vainer, C. B. (2011). Cidade de exceção: Reflexões a partir do Rio de Janeiro. Anais dos Encontros Nacionais da ANPUR, Rio de Janeiro, Brasil.

Vainer, C. B. (2013). Pátria, empresa e mercadoria. Notas sobre a estratégia discursiva do planejamento estratégico urbano. Anais dos Encontros Nacionais da ANPUR, Rio de Janeiro, Brasil.

Watts, J. (2015, August 4). The Rio property developer hoping for a $\$ 1 \mathrm{bn}$ Olympic legacy of his own. The Guardian. Retrieved from http://www. theguardian.com

Weber, R. (2002). Extracting value from the city: Neoliberalism and urban redevelopment. Antipode, 34(3), 519-540. doi:10.1111/14678330.00253 